\title{
Authentic African community development practices in a diverse society: A transdisciplinary approach
}

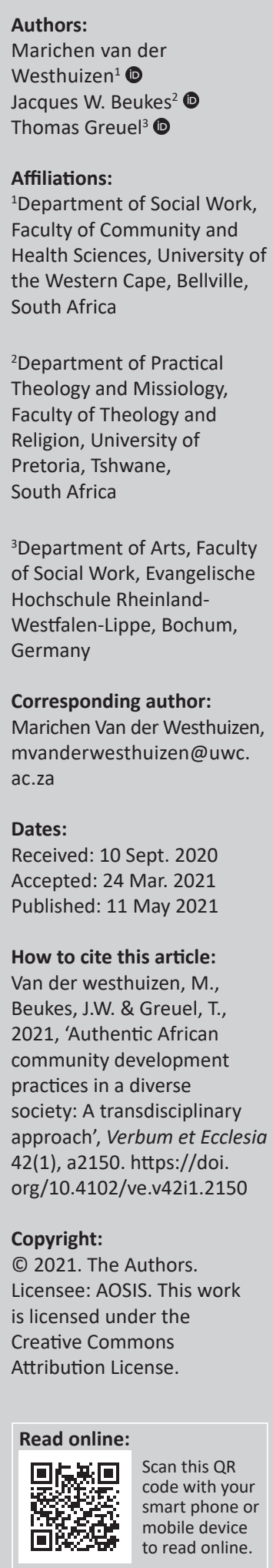

The South African people continuously engage in social actions characterised by intolerance, pointing to frustrations and disillusionment in a post-apartheid era. A need to find creative ways to engage diverse communities to work together to participate in their own development and well-being was identified. This article is based on long-term transdisciplinary discourse and work. The aim is to explore how the disciplines of social work, theology and the arts could contribute together towards the development of communities where participation, collaboration and cooperation as key principles of authentic community development are actively implemented. Within a transdisciplinary framework, the disciplines engaged in participatory research projects that resulted in findings that informed the development of a process where people at grassroots level become aware and more tolerant of each other, begin to work together and as such become involved in their own futures. It is concluded that by encouraging participation, collaboration and cooperation in social change processes, the South African people can be empowered towards working together and becoming involved in their own futures.

Intradisciplinary and/or interdisciplinary implications: The disciplines of social work, theology and the arts entered into a transdisciplinary dialogue and work over the past years. The transdisciplinary team engaged in four participatory research projects to include input from grassroots levels to inform their understanding of how the different disciplines can better contribute towards a process of authentic community development in the diverse South African society. This resulted in the process proposed in this article.

Keywords: authentic community development; Africanisation; diverse society; transdisciplinary approach; social work; theology; the arts; social change.

\section{Introduction}

Although various socio-economic and political changes can be identified in South Africa's ${ }^{1}$ 26 years into democracy (cf. Beukes 2016; Haddad 2016:7; Koopman 2005:150; Pieterse 2001:75.), Van der Westhuizen, Greuel and Beukes (2017) and Prinsloo (2016) discussed how practices to address social issues in the South African society are not always informed by active participation of the South African people, leading to frustrations and a feeling of not being heard and not being respected. This is evident in various social actions and protests, against, amongst others, poor service delivery, gender-based violence, as well as xenophobic acts of violence and intolerance. Also, the Ipsos' People's Poll (2016) found that two-thirds of South African citizens are worried that the country is going in the wrong direction because of matters that undermine democracy. Further illuminating the frustrations of citizens, more than half of South Africans who participated in the above-mentioned survey reported that they do not expect a positive change. This occurs despite the fact that post-apartheid policy documents clearly indicate the inclusion of social development as the approach to ensure that the diverse South African people are empowered and included in processes that are aimed at social justice through improving the lives of all citizens. However, the challenge to move towards a socially just postapartheid South Africa is unique. The uniqueness of South Africa's apartheid era lies in the systematic way in which the National Party, which came into power in 1948, formalised segregation through legislation, leading to 'a particular form of colonialism not experienced by other nations of Africa' (Haddad 2016:2).

Reflecting on the impact of the interplay between colonialism and apartheid, Louw (2010) concurred that the South African people experience an added challenge to build a new identity

1.We view South Africa as a specific context within Africa. 
as both South Africans and as Africans. In order to move forward and away from colonialism and apartheid, which officially ended in 1994, the African heritage must now become a central part of future ways of thinking and doing. This viewpoint supports Makgoba's (1997) description of the term 'Africanisation'. According to this author, one cannot forget the past, and therefore one cannot exclude the European influences of the past. The author suggests that, whilst acknowledging European viewpoints and practices, the African identity and culture should be affirmed and included in the way African people move forward. Africanisation of how African people deal with different issues should, therefore, become a way in which they ensure that what they think, how they think and what they do are influenced by the reality of their specific context. We acknowledge that Africa is rich in cultures and that different contexts should be considered when working towards an Africanised understanding. Furthermore, the term 'Africanised' should not be a mere concept but should be transformed into a working concept. Africanisation, therefore, implies that (Van der Westhuizen et al. 2017):

$[P]$ raxis is informed by the reality of the South African context, the viewpoints of the people of South Africa and their descriptions of what is needed to build a just society. (p. 1)

Community development is one approach to work towards a change process where social justice is actively implemented. This approach falls within the social development paradigm and supports a movement from the state satisfying the needs of the citizens to a facilitation of processes where citizens themselves become involved in their futures (Hart 2012; Van der Westhuizen et al. 2017). Therefore, in order to work towards such a movement, the transdisciplinary team representing social work, theology and the arts started their discourses and work based on a shared argument that citizens must become aware of the diverse indigenous resources, such as knowledge and skills, available to them to stimulate collaborative and participative positive change in communities.

\section{Methods used in the transdisciplinary discourse and work}

The disciplines of social work, theology and the arts have entered into transdisciplinary dialogues and work over the past 8 years. The transdisciplinary team engaged in four participatory research projects to include inputs from grassroots level to inform their understanding of how the different disciplines can better contribute towards a process of authentic community development in the diverse South African society.

The participatory research project followed a qualitative exploration of how multicultural groups experienced and perceived collaborative activities and how it contributed to (1) their understanding of their own cultural identities, (2) understanding, attitude and behaviour towards individuals and groups with other cultural identities, (3) their ability to develop a shared goal and (4) their ability to work together towards the shared goal. The findings presented in this article culminated from four projects that followed the same methods and process. Participants consisted of diverse members of communities that volunteered to engage with an intercultural project, using musical activities to create a shared experience. Data were collected through reflective individual and focus group interviews and analysed through thematic analyses by each discipline. The findings were then compared and led to discourses where a shared understanding and interpretation of the findings led to the final development of the process presented in this article. Based on the participatory nature of this study, the participants were presented with the findings to provide their input. Ethical considerations included voluntary participation, informed consent, confidentiality and the management of data.

The findings enabled the team to identify a process from which to approach authentic community development, which will be unpacked in this article. Firstly, we will discuss the characteristics, principles and outcomes of authentic community development as an approach to the Africanised development of a diverse society. Secondly, we will propose the transdisciplinary approach as a framework to utilise as a lens through which to explore authentic community development processes. Thirdly, we will introduce a transdisciplinary process and the social dimensions of music towards authentic community development. We will conclude this article by providing clear steps, developed through transdisciplinary work, to include in a process that creates creative and non-threatening spaces for interactions that could inform authentic community development.

\section{Characteristics, principles and outcomes of authentic community development}

The terms 'social welfare', 'social development' and 'community development' may be viewed as inter-related. Social welfare refers to programmes, benefits and services that are offered by religious, voluntary, non-government and government organisations to individuals, groups and communities. Social development may be viewed as a part of social welfare, focusing on activities/actions directed at social, economic, education and health development (Green 2012). It is specifically aimed at poverty alleviation, where the government addresses this issue together with social and economic sectors (Green 2012). The danger exists, however, that it becomes a top-down approach and that people affected by social issues are then not provided with platforms to share their understandings, experiences and ideas on how to address these issues. In line with this concern, the United Nations Educational, Scientific and Cultural Organization (UNESCO 2011) affirms that community development must focus on social justice where human wellbeing is, amongst others, supported through the development of sustainable social relations.

Drawing a link between social and community development, Geoghegan and Powell (2006) asserted that community 
development is an approach within social development where democratic governments aim to maximise socialeconomic development through partnerships and social development policies to facilitate a process of sustainable development. In community development, a unique leadership style is needed to facilitate partnerships between government and role-players, stakeholders and communities, with specific emphasis on empowerment and participation strategies to attain sustainable and collective change, inclusion and equality within communities (Hart 2012; Korten 1990). Community development is furthermore based on the rights-based approach, as it is a participation-driven process where both service providers and users are responsible for the planning, implementation and monitoring of services. The right to obtain support is also linked to the responsibility to participate. As such, development is based on the willingness to take ownership of a situation and to join hands to find solutions (Weyers 2011). Characteristics of community development include that the community as a whole is seen as a system, with interdependent subsystems that join hands in order to work together for the 'common good' through participation and cooperation, with networking and collaboration as key factors to success. The inclusion of subsystems means that intervention takes place at grassroots level. It is based on the belief that the community leaders, together with the community members, are best qualified to identify and deal with contextual needs and problems through the inclusion of internal knowledge and skills. The strategy is, therefore, the mobilisation of the community to address their needs and problems, whilst intervention emphasises cooperation, group capacity building and consultation. Community mobilisation focuses on a collaborative capacity and community development process through which local groups and/or organisations identify needs, develop an outline of an action plan and then implement it. With the emphasis on capacity building, the process aims to develop skills, leadership and to create selfsupportive services, groups and structures to improve sustainable growth and independent functioning through cooperation and participation (Weyers 2011). The inclusion of participation, collaboration and cooperation as part of the community development process leads to authentic community development because it is truly based on the inclusion of the voices of the people in the community.

It should be noted that the focus on providers and beneficiaries and the lack of democratic inclusion and participation in services in the previous dispensation, and arguably in the current dispensation, created a platform for dependency that inhibited personal and socio-economic growth (Harvey \& Lind 2005). To address this, community involvement is viewed within the framework of stimulating growth towards independent living, which is key to authentic community development. The principles of authentic community development include social justice in that it informs the movement towards a participatory and shared set of values focusing on tolerance, diversity, human rights and a liberal democracy (Swartz 2006). In order to facilitate a socially just community development process, the implementation of the principles of community development requires '...emotional maturity and compassion with the circumstances of people' (Waghid 2004:525). Waweru (2015) identified the following principles that we viewed as complementary to social justice and needed for praxis that involves African knowledge and skills to guide community development processes.

- Consciousness-raising: An awareness of own perceptions, behaviour and needs must be complemented by an awareness of the perceptions, behaviour and needs of others within the community. Through consciousnessraising, authentic community development should lead to tolerance between groups and to the development of abilities to work together without one group ruling over another group.

- Participation: The authenticity of community development lies in the structures and processes that involve networks and partnerships with all role-players. Waweru (2015) explains that participatory practices change top-down practices to a bottom-up status informed by selfmotivation and involvement.

- Empowerment: The focus is on practices that stimulate the development and expansion of knowledge, understanding and skills, which leads to the experience of 'we did it ourselves'. Empowerment supports the active implementation of social justice as it leads to selfdetermination, self-help and self-reliance. Community development, from this principle, aims to increase democracy and the sharing of power.

- Ownership: This involves a process where people will engage in the whole process, from visioning, conceptualising, planning and implementation of community projects.

- Valuing local: Indigenous resources are valued as more applicable and sustainable than interventions coming from outside. This principle also acknowledges that local cultural practices should be valued as a key component of community development. The interventions should relate to these practices and should lead to an experience of self-worth.

- Organic development: Grassroots actions based on contextualised experiences, perceptions and needs are viewed as organic when development starts and grows as a result of felt needs. Therefore, actions are based on home-grown needs-assessment, planning and implementation of strategies to address well-being within a community. This principle places the focus on the respect of the inherent abilities that can be found within local communities.

- Inclusivity and community-building: These two principles go hand-in-hand as inclusivity encourages relationshipbuilding, which is aimed at creating a sense of belonging. Social justice is an outcome as it emphasises equal opportunities for and contributions from all sections of the community.

- Diversity: This principle is aimed at the development of tolerance and acknowledges all the different groups within a community. It is aimed at valuing the different resources, knowledge, skills and understandings that contribute to a 
better 'whole'. According to the diversity principle, contextualising different actions is a crucial component to ensure that tolerance, respect and human dignity are included in the community development process.

- Sustainability: This principle focuses on inter- and intragenerational interdependence. It means that today's actions must not compromise tomorrow's needs. Longterm change that benefits the whole community is, therefore, a preferred outcome of authentic community development.

From the above description, the transdisciplinary team identified four preferred outcomes of authentic community development that can also be seen as a process, namely:

1. Community-building: This forms the first step towards authentic community development and serves as the foundation for sustainable development. Through consciousness-raising and activities that encourage the development of awareness of the self and others, indigenous knowledge is identified and included valuing local practices. It involves a participatory needs assessment. Organic development is stimulated through the implementation of principles of consciousnessraising, valuing local practice and participation.

2. Community-bridging: During the second step, initiatives are aimed at the development of social cohesion, cooperative activities and joint planning of projects that will contribute to the development of the whole community. Through participation, principles of inclusivity, diversity, empowerment and ownership are included in activities.

3. Community action: This evolves from the social cohesion that was established during the second step. To ensure the sustainability of actions, participation, empowerment and ownership form key to actions in and by the community members themselves (Lang et al. 2012).

4. Belonging: A final preferred outcome of authentic community development is that it should lead to a sense of belonging for all the members in a particular community to support the active implementation of social justice (Van der Westhuizen, Beukes \& Smith 2019).

\section{Africanising authentic community development}

With the aim to contribute to a praxis that mobilises authentic community development, we aimed to unmask those aspects that prevent Africanised knowledge and skills from being recognised and developed (Razack 2009). We also took note that whilst South African legislation and policies acknowledge the inclusion of citizens, the ongoing social issues of intolerance, violence, poverty and so forth indicate that the implementation of principles such as participation, collaboration and cooperation should be critically reviewed. The transdisciplinary discourse, therefore, included reflections on how the past influences the present.

The colonised eras resulted in a serious marginalisation of African ways of being, knowing and doing, with the consequence that the minds of African people were colonised, even after the end of apartheid (ASASWEI 2016). Therefore, the influences of the past still linger on. In line with this viewpoint, Tamburro (2013) referred to multigenerational trauma because of colonisation. The colonisation of the mind, meaning a lack of self-worth based on not being heard, that lingers on after the end of apartheid can be addressed when we start to not only hearing the perspectives, experiences and needs of the people but when we start to act on these expressions showing that the viewpoints of those on grassroots level matter.

Decolonisation requires that we actively engage with processes based on a desire to reclaim and revaluing the African socio-economic heritage or culture (ASASWEI 2016). It should be noted that, if we intend to decolonise and acknowledge the African praxis and ways of doing, knowing and being, we must be informed by the African people and utilise this information to inform praxis (cf. Van der Westhuizen et al. 2017). In line with this viewpoint, Thabede (2008:234) explained that an African worldview reflects the '...African cultural beliefs, praxis and values'. This means that we should effectively include the African worldview when we attempt to explore social phenomena in the African context. It also requires a willingness to enter into a process of challenging existing knowledge and praxis (Dumbrill \& Green 2008). The Africanisation of our knowledge and skills serves as a stimulus to create transformation towards a decolonised society. Through a transdisciplinary approach, we need to ensure that we hear the relevant voices and that we become sensitive towards the deeper meaning of the impact of ignoring the plights of people living in the realities of present-day contexts (Van der Westhuizen et al. 2017). This then becomes the foundation for sustainable transformation.

\section{A transdisciplinary approach to authentic community development}

Transdisciplinary work moves beyond the bridging of understanding of social issues. It engages in a search for solutions through a collaborated effort between disciplines (Toomey et al. 2015). Therefore, transdisciplinary work refers to a concerted effort between disciplines that create a movement across the disciplines and result in a product beyond all disciplines (Nicolescu 2005). We were interested in a transdisciplinary approach, as it is a strategy that works across disciplines to identify a more holistic understanding of a specific issue. Castree, Adams and Barry (2014) argue that such an approach can contribute to a new focus on the inclusion of an understanding of human diversity and social inequality within a specific context, which relates well to our exploration of authentic African community development practices in the diverse South African society.

Typical of the transdisciplinary approach, all disciplines involved in a specific field work together and learn from each other through joint research on grassroots level to 
TABLE 1: Service professions and the arts - Towards authentic community development.

\begin{tabular}{|c|c|c|c|}
\hline Service professions & Transdisciplinary approach & Authentic community development & The arts: Making music together \\
\hline Social work & - Collaborative needs assessment/problem & - Consciousness-raising & - Non-threatening method towards \\
\hline Theology & 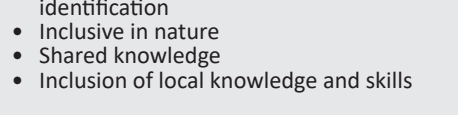 & $\begin{array}{l}\text { - Empowerment } \\
\text { - Valuing local and organic development } \\
\text { - Inclusivity } \\
\text { - Siversity } \\
\text { Sustainability }\end{array}$ & $\begin{array}{l}\text { community-building and bridging } \\
\text { - Becoming aware of self and others } \\
\text { - Exploring local cultural practices and skills } \\
\text { Corking towards cooperation and } \\
\text { collaboration }\end{array}$ \\
\hline
\end{tabular}

develop services and products. A key component is that it also involves the voices of the users of such services (Van der Westhuizen et al. 2017). Hinkel (2008) explained in this regard that the transdisciplinary approach is particularly useful to address problems that cannot be solved by a single discipline and also not by science alone. In summary, this approach focuses on interpretation, language, discourse and meaning from different perspectives that are harmonised and integrated. The importance of including the people affected by the problem to find effective solutions further aligns well with the characteristics and principles of authentic community development.

The transdisciplinary team acknowledged the diversity and post-apartheid challenges within the South African context. We were interested in contributing to the social sciences (Toomey et al. 2015) by finding a practical process to assist communities to develop in an organic manner. In support of this, Abdi (2006:16) explained that we have to revisit our epistemology of what we know, how we know it and what we need to know in order to 'develop diverse trajectories of knowing and constructing select bodies of knowledge'.

The link between the disciplines of social work, theology and the arts, the transdisciplinary approach and community development are depicted in Table 1.

Whilst social work and theology are both disciplines aimed at improving the quality of lives of and interactions between people (cf. George 2012; Thesnaar 2012; Van der Westhuizen \& Kleintjes 2015), the arts becomes the vehicle to create awareness and to promote communication between individuals, groups and communities in a non-threatening manner (Kinnunen \& Kaminski 2003). Joint musical activities include cultural diversity being viewed as an asset and an opportunity for communities to learn from each other. The inclusion of the discipline of the arts was also based on the viewpoint that the reality of diverse communities does not only challenge economic and social structures but also involves symbolic and cultural issues that should be addressed in a creative and non-threatening manner (European Commission 2014).

The transdisciplinary approach acknowledges the conflicts between different perceptions and understanding and supports the principles of participation, cooperation and collaboration in search of a new collective understanding of a particular context (Leiner \& Fläming 2012). An important prerequisite is a willingness to explore new ways of understanding through a cooperative process. It requires an openness to learn from other disciplines and grassroots level to productively discuss the work of other disciplines, to develop new innovative processes and to develop new materials such as texts and toolkits to address social needs (Mittelstraß 2005).

Through this approach, we were able to include a bottom-up strategy, whilst all those involved in the transdisciplinary team had to be willing to share knowledge and skills and to learn from other disciplines and participating community members to develop a unique understanding of the context. As a result, the different members of the team became able to use knowledge and skills from another discipline, whilst integrating this with the knowledge and skills from their own discipline (Stock \& Burton 2011). Nissani (1995:121) explained that distinctive components of two or more disciplines are being integrated into 'a single mind'. In this way, the disciplines develop a unique and integrated way of developing knowledge, understanding and skills. In addition to sharing existing knowledge and skills between the disciplines, the single-mindedness of the transdisciplinary approach also moves towards obtaining new knowledge, understanding and skills that reflect multiple viewpoints (Van der Westhuizen et al. 2017). With a specific focus on working towards contextual African community development, the transdisciplinary team worked together to develop a new knowledge and skills base with the aim to address context-related realities, as well as to move towards decolonised praxis. Throughout this learning process between, across and beyond the disciplines, the voices of the people at grassroots level are incorporated in the development of a new understanding.

In order to frame the actions to be taken towards the outcomes of authentic community development, we used a transdisciplinary process and the social dimensions of joint music.

\section{A transdisciplinary process and the social dimensions of music towards authentic community development}

Past and present socio-economic and political trends represent external facets that dominate communities' wellbeing. This then leads to internal facets that prevent communities to decolonise their minds and to develop ownership for their own lives and futures. Internal facets include stagnation or an attitude of 'this is as good as it gets', disempowering emotions, a lack of participation and excessive conflict situations (Van der Westhuizen et al. 2017; Weyers 2011). We attempted to Africanise our understanding 
of internal facets with the aim to create a space where the people of the country could find hope for a better future (Villanueva 2013). Working within the community development framework, our goal was to create a community identity, vision and hope (Weyers 2011). The objectives were (1) to stimulate interest in an effort to encourage participation, (2) to promote unity, (3) to acknowledge negative or painful emotions, attitudes and behaviours and to explore the origins thereof, (4) to explore opportunities to explore African ways of dealing with problems and (5) to explore knowledge, understanding and skills that could address societal problems.

We framed our own discourses related to our shared interest, namely, authentic community development in a diverse context, in the hermeneutical learning process and combined this with the phases of appreciative inquiry. The theory of appreciative inquiry was included as it is similar to participatory research where the aim is to involve all roleplayers, encourage conversation and interconnectedness and identify and build on collective strengths (Cooperrider Whitney \& Stravos 2008). It resulted in an identification of four inter-related phases that guided our discussions and the planning of the participatory research (cf. Cooperrider et al. 2008; Van der Westhuizen \& Greuel 2016):

- Argentic learning of the relevant social systems consciously reflecting and asking: What is happening?

- Conceptualising through abstract learning skills developing an image of the cultural meaning by asking: What does it mean?

- Communal and multidimensional learning - testing different options to attain authentic community development by asking: What have we learnt?

- Interactional and concrete learning - planning actions by asking: What do we do, based on what we learned?
As an outcome of the transdisciplinary discourses and the participatory research, we integrated the outcomes of authentic community development with the transdisciplinary process proposed by Lang et al. (2012) and used the findings of the mentioned research projects to identify actions in each phase of the process and how musical activities would be used as communication and to collect the qualitative data, as illustrated in Table 2.

In order to create non-threatening spaces to encourage a transdisciplinary discourse through appreciative inquiry, as well as an intercultural grassroots concerted effort to work towards authentic community development, the arts as a discipline within the transdisciplinary framework becomes essential. As described in the Table 2, we used joint musicmaking as an art form. The social powers of music (Koelsch 2012) were therefore adapted to the following social dimensions to be used as an integrated tool for authentic community development (Greuel 2019):

- When individuals make music together, they come into contact with each other.

- Hearing is a central component of making music together. People who make music together must both be heard by the other group members and hear the other group members. This creates an awareness of each other within the group.

- A convincing musical performance by multiple players is only possible if it involves cooperation between players. Cooperation implies a shared goal, and engaging in cooperative behaviour is an important potential source of shared pleasure.

- People synchronise their motoric activities to enter a common rhythm, and also to stay in the same rhythm. This requires mutual perception and appropriate mindfulness or social cognition. The synchronised activities are not necessarily uniform, which supports inclusivity.

TABLE 2: A transdisciplinary process of authentic community development.

\begin{tabular}{|c|c|c|c|}
\hline $\begin{array}{l}\text { Authentic community } \\
\text { development outcomes }\end{array}$ & Actions & Transdisciplinary process & The use of musical activities \\
\hline Community-building & $\begin{array}{l}\text { Needs-assessment } \\
\text { - Bottom-up grassroots exploration } \\
\text { - Problem identification and formulation } \\
\text { Principles of participation, consciousness-raising } \\
\text { and organic development }\end{array}$ & Problem-formulation and team building & $\begin{array}{l}\text { Members present themselves through } \\
\text { choosing a song, which could also include } \\
\text { dance, to present themselves, their dreams, } \\
\text { frustrations, or fears the best. } \\
\text { Each member is therefore confronted with the } \\
\text { questions: } \\
\text { - Why am I participating? } \\
\text { What do I want fellow members to know } \\
\text { about me? Do I need the fellow members } \\
\text { to hear? }\end{array}$ \\
\hline Community-bridging & $\begin{array}{l}\text { Discourses aimed at developing understanding of } \\
\text { the context and problem/need to be addressed } \\
\text { from a variety of viewpoints } \\
\text { - Principles of inclusivity, diversity, empowerment } \\
\text { and ownership }\end{array}$ & $\begin{array}{l}\text { Co-creation of solution-orientated and } \\
\text { transferrable knowledge }\end{array}$ & $\begin{array}{l}\text { Members present themselves musically. This } \\
\text { results in discussions that focus on: } \\
\text { - What did we hear from each other? } \\
\text { - What are our similarities? } \\
\text { - What are our differences? } \\
\text { - How do our similarities/differences create } \\
\text { an opportunity for working together? } \\
\text { - How can our similarities/differences create } \\
\text { a challenge for working together? }\end{array}$ \\
\hline
\end{tabular}


TABLE 3: A transdisciplinary authentic community development process.

\begin{tabular}{l} 
Hermeneutical learning process \\
What is happening? \\
Understanding (prejudice, reflection and conversation) \\
- Different subgroups are identified and invited to \\
participate \\
- Individual members engage in reflections of own \\
context \\
- Subgroups engage in group reflections to discover \\
differences and similarities \\
- Subgroup members work towards a presentation of \\
the individuals and the group \\
What does it mean? \\
Explanation (reflection, reconstruction and \\
conversation) \\
- Subgroups come together \\
- Subgroups present themselves to each other \\
- Engagements in terms of doing things together as a \\
multicultural group \\
- Discovering differences and similarities \\
What have we learnt? \\
Explanation (reflection, reconstruction and \\
conversation) \\
- The multicultural group is introduced to a joint \\
activity \\
- The group must identify a shared goal for the activity \\
that acknowledges the differences and similarities of \\
group members and subgroups \\
- They are supported to plan and implement the joint \\
activity \\
What do we do? \\
Interpretation (conversation and fusion) \\
- Acceptance of new understanding (meaning) based \\
on the new experiences and decision to maintain \\
change process \\
- Identify key aspects that define the multicultural \\
Plan activities that address the multicultural group's \\
needs \\
\hline
\end{tabular}

Appreciative inquiry

Social dimensions of music

Discover: Learning: Becoming aware of oneself and

Contact and a lack of competition

others

- Exploring the expression of meaning through music

- Acceptance of current understanding (meaning) based on past experiences and decision to enter the change process

- Creating a safe space to enter into communication,

focussing on different levels of functioning

- Individual reflection, creative exercises and

opportunities to share

- Subgroup musical activities to explore own context

- Sharing through musical experiences

Developing a subgroup presentation that represents the individual group members and the nature of the subgroup (reflecting contextualised African knowledge and skills)

Dream: Learning: Becoming aware of oneself and

others

- Creating a safe space to enter into communication, focussing on different levels of functioning

- Individual and collective experience opportunities to share

Contact, cooperation, synchronisation, affect

atonement and a lack of competition

- Musical presentations of subgroups

- Activities to establish rhythm (synchronise) between subgroups

- Establishing give-and-take principles

- Encouraging participation and individual contributions

Design: Changing: Awareness and new understanding Contact, cooperation, synchronisation, affect to develop a new vision for positive change and

development

- Individual and collective experience

- Individual reflection, creative exercises and atonement, social cohesion and lack of competition

- Establishing rituals

- Planning content, leadership roles, structure and opportunities to share inclusion

- Finding common ground

Destiny: Doing: New behaviour

- Individual and collective experience

- Finding common ground
Contact, cooperation, synchronisation, affect atonement, social cohesion and lack of competition - Establishing rituals

- Reflect on outcomes and make adjustments

- Planning content, leadership roles, structure and inclusion

Source: Van der Westhuizen and Greuel 2016

- In addition to synchronisation, emotions are shared, which leads to affect atonement and a feeling of mutual understanding or co-pathy.

- As an effect, music leads to increased social cohesion of a group and a feeling of belonging.

- People do not have to strive for superiority and can survive without competition, further supporting inclusivity and a sense of belonging.

The learning process described above resulted in a framework for authentic African community development praxis with which we will conclude this discussion.

\section{Conclusion: A framework for authentic African community development praxis}

Our shared interest was the development of authentic African community development practices to encourage a movement towards decolonised community building, bridging and action through a sense of belonging. The final outcome of the transdisciplinary discourses and the participatory research projects resulted in an integration of a hermeneutical learning process through appreciative inquiry and the use of the social dimensions of music, as illustrated in Table 3.

We aimed to contribute to authentic community development through the transdisciplinary participatory research that informed this discussion. We used music as a non-threatening and non-verbal communication method to serve as a vehicle to work towards social justice, where community members experience a sense of inclusion and belonging. We hoped to contribute to a process of postcolonial healing through this contribution. The final aim was to assist communities to find creative ways to use their African knowledge and skills to become active participants in their own futures. We conclude this discussion with the words of Van der Westhuizen, Greuel \& Thesnaar (2018):

Change requires change.

It starts with a genuine desire and hope for a better future for yourself and for others.

It requires a willingness to move your energy towards this future and away from the past and it requires honesty with yourself.

Change happens when you become willing to start with yourself, reach out to others and engage in processes where you move to a new way of thinking, doing and being.

\section{Acknowledgements Competing interests}

The authors declare that they have no financial or personal relationships, which may have inappropriately influenced them in writing this article.

\section{Authors' contributions}

M.V.d.W. and T.G. conducted research that informed this study. This article is not a report of the research findings, but of how the research informed our transdisciplinary understanding of authentic African community development 
practices in a diverse society. By means of transdisciplinary discourse and work, the findings of the research have been utilised to inform academic content that was developed by all three authors, namely, M.v.d.W., J.W.B. and T.G. The strategic options discussed in this article therefore emanated from both the research findings and the development of academic content.

\section{Ethical considerations}

This article followed all ethical standards for research without direct contact with human or animal subjects.

\section{Funding information}

This research received no specific grant from any funding agency in the public, commercial or not-for-profit sectors.

\section{Data availability}

Data sharing is not applicable to this article as no new data were created or analysed in this study.

\section{Disclaimer}

The views and opinions expressed in this article are those of the authors and do not necessarily reflect the official policy or position of any affiliated agency of the authors.

\section{References}

Abdi, A.A., 2006, 'Eurocentric discourses and African Philosophies and epistemologies of education: Counter-hegemonic analyses and responses', International Education, Fall Edition: $15-31$, viewed 14 August 2013 , from https://
eric.ed.gov/?redir=http $\% 3 a \% 2$ f $\% 2$ fcehhs.utk.edu $\% 2$ fpublications $\% 2 \mathrm{fIE} \% 2 \mathrm{fgen}$ eralinfo.html.

Association of South African Social Work Education Institutions (ASASWEI), 2016, Decolonising social work education in South Africa. A report emerging from a

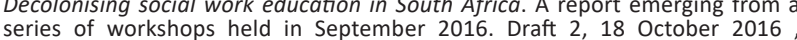
series of workshops held
ASASWEI, Johannesburg.

Beukes, J.W., 2016, Belhar en 'n Teologie van Ontwikkeling in 'n Konteks van Armoede en Ongeregtigheid, Sun Media, Stellenbosch.

Castree, N., Adams, W.M. \& Barry, J., 2014, 'Changing the intellectual climate', Nature Climate Change 4, 763-768. https://doi.org/10.1038/nclimate2339

Cooperrider, D.L., Whitney, D. \& Stavros, J.M., 2008, Appreciative inquiry handbook For leaders of change, 2nd edn., Berrett-Koehler Publishers, Oakland, CA.

Dumbrill, G.C. \& Green, J., 2008, 'Indigenous knowledge in the social work academy', Social Work Education 27(5), 489-503. https://doi. org/10.1080/02615470701379891

European Commission, 2014, European agenda for culture, European Commission Directorate General for Education and Culture, Brussels.

Geoghegan, M. \& Powell, F., 2006, 'Community development, partnership governance and dilemmas of professionalisation: Profiling and assessing the case of Ireland', British Journal of Social Work 36(5), 846-861. https://doi.org/10.1093/bjsw/bch344

George, J., 2012, 'Intercultural theology: An approach to theologizing in the context of pluralism and globalization', Master of Theology Degree thesis, Toronto School of Theology, Toronto.

Green, S., 2012, 'Towards a developmental approach to social welfare: Social welfare policy in post-apartheid South Africa', in I. Swart, A. Gouws, P. Pettersson, J. Erasmus \& F. Bosman (eds.), Welfare, religion and gender in post-apartheid South Africa, pp. 27-42, SUN Press, Stellenbosch.

Greuel, T., 2019, 'Miteinander verbunden: Soziale und gesellschaftliche Dimensionen des gemeinsamen Musizierens', Üben \& Musizieren: Zeitschrift für Instrumentalpädagogik und muskalisches Lernen 1(19), 6-11, viewed 24 January 2020, from https://uebenundmusizieren.de/artikel/miteinander-verbunden/.

Haddad, B., 2016, 'Curriculum design in theology and development: Human agency and the prophetic role of the church', HTS Teologiese Studies/Theological Studies 72(4), 1-8. https://doi.org/10.4102/hts.v72i4.3432

Hart, C.S., 2012, 'Professionalisation of community development in South Africa: Process, issues and achievements', Africanus 42(2), 55-66, viewed 18 April 2015, from https://hdl.handle.net/10520/EJC136728.
Harvey, P. \& Lind, J., 2005, Dependency and humanitarian relief. HPG Research Report 29, Overseas Development Institute, London.

Hinkel, J., 2008, 'Transdisciplinary knowledge integration. Cases from integrated assessment and vulnerability assessment', PhD thesis, Wageningen University, Wageningen.

Ipsos 2016, People's Poll: The country is going the wrong direction, viewed 20 February 2017, from http://www.ipsos.co.za/SitePages/Latest $\% 20$ Press $\% 20$ and $\% 20$ News.aspx.

Kinnunen, K. \& Kaminski, W., 2003, Enhancing cultural awareness through cultural production, Kauniainen Unit of Humanities Polytechnic and the Korpilahti Unit of Humanities Polytechnic \& University of Applied Sciences, Cologne.

Koelsch, S., 2012, Brain and music, John Wiley \& Sons, Oxford.

Koopman, N., 2005, 'After ten years: Public theology in post-apartheid South Africa Lessons from a debate in the USA', Nederduitse Gereformeerde Teologiese Tydskrif 46(1/2), 149-163.

Korten, D.C., 1990, Getting to the 21st century: Voluntary action and the global agenda, Kumarian Press, West Hartford.

Lang, D.J., Wiek, A., Bergmann, M., Stauffacher, M., Martens, P., Moll, P. et al., 2012, Sustainability science: Bridging the gap between society 7(1), 25-43. https://doi. org/10.1007/s11625-011-0149-x

Leiner, M. \& Fläming, S., 2012, Latin America between conflict and reconciliation, Vanden Hoeck \& Ruprecht, Göttingen.

Louw, W., 2010, 'Africanisation: A rich environment for active learning on a global platform', Progressio 32(1), 42-54, viewed 12 May 2018. from http://hdl.handle. net/10500/4999.

Makgoba, M.W., 1997, Mokoko: The Makgoba affair - A reflection on transformation, Vivlia, Florida Hills, FL.

Mittelstraß, J., 2005, “"Methodische Transdisziplinarität”, Technikfolgenabschätzung', Theorie und Praxis 14(2), 18-23, viewed 19 September 2015, from http://www. scielo.org.za/scielo.php?script=sci nlinks\&ref=3401706\&pid=S2305$445 \times 201500010002500028 \& \operatorname{lng}=$ en.

Nicolescu, B., 2005, 'Towards transdisciplinary education and learning', Paper prepared for conference on 'Science and Religion: Global Perspectives', Metanexus Institute, Philadelphia, PA, 4th-8th June 2005.

Nissani, M., 1995, 'Fruit salads and smoothies: A working definition on interdisciplinarity', Journal of Educational Thought 29, 121, viewed 29 January 2016, from https://www.jstor.org/stable/23767672.

Pieterse, H.J.C., 2001, 'The human face of God for the poor', Praktiese Teologie in Suid-Afrika 16(1), 75-104.

Prinsloo, E.H., 2016, 'The role of the Humanities in decolonising the academy', Arts \& Humanities in Higher Education 15(1), 164-168. https://doi. org/10.1177\%2F1474022215613608

Razack, N., 2009, 'Decolonizing the pedagogy and praxis of international social work', International Social Work 52(1), 9-21. https://doi. social Work', International Social
org $/ 10.1177 \% 2$ F0020872808097748

Stock, P. \& Burton, J.F., 2011, 'Defining terms for integrated (multi-inter-transdisciplinary) sustainability research', Sustainability 3(8), 1090-1113. https://doi. org/10.3390/su3081090

Swartz, S., 2006, 'A long walk to citizenship: Morality, justice and faith in the aftermath of apartheid', Journal for Moral Education 35, 551-570. https://doi. org $/ 10.1080 / 03057240601012287$

Tamburro, A., 2013, 'Including decolonization in social work education and praxis', Journal of Indigenous Social Development 2(1), 1-16, viewed 20 March 2015 from http://hdl.handle.net/10125/29814.

Thabede, D., 2008, 'The African worldview as the basis of praxis in the helping professions', Social Work/Maatskaplike Werk 44(3), 233-245, viewed 20 March 2015, from https://socialwork.journals.ac.za/pub/article/view/237/219.

Thesnaar, C.H., 2012, 'A pastoral hermeneutical approach to reconciliation and healing: A South African perspective', in M. Leiner \& S. Fläming (ed.), Latin
America between conflict and reconciliation, pp. 215-229, Vanden Hoeck \& America between confl
Ruprecht, Göttingen.

Toomey, A.H., Markusson, N., Adams, E. \& Brockett, B., 2015, Inter- and transdisciplinary research: A critical perspective. Lancaster Environment Centre, disciplinary research: A critica
Lancaster University, Lancaster.

United Nations Educational, Scientific and Cultural Organization (UNESCO), 2011, Key arguments for a strong commitment to cultural diversity and intercultural arguments for a strong
dialogue, UNESCO, Paris.

Van der Westhuizen, M.A. \& Greuel, T., 2016, Leading intercultural musical projects to create a 'sense of community': A community development approach, Hugenote Kollege \& Evangelische Hochschule Rheinland-Westfalen Lippe, Bochum \& Wellington.

Van der Westhuizen, M., Greuel, T. \& Beukes, J.W., 2017, 'Are we hearing the voices? Africanisation as part of community development', HTS Teologiese Studies/ Theological Studies 73(3), 4512. https://doi.org/10.4102/hts.v73i3.4512

Van der Westhuizen, M.A., Greuel, T. \& Thesnaar C.H., 2018, From my own, to the foreign and back to my own: A practical journey for intercultural awareness and tolerance, Christian Literature Fund (CLF), Wellington.

Van der Westhuizen, M.A. \& Kleintjes, L., 2015, 'Social work services to victims of xenophobia', Social Work/Maatskaplike Werk 51(1), 115-134. https://doi. org/10.15270/51-1-431

Van der Westhuizen, M., Smith, R. \& Beukes, J.W., 2019, 'Exploring the social function of congregations: A community development approach to develop "hub-andspill" early childhood development centres', HTS Teologiese Studies/Theological Studies 75(2), a4850. https://doi.org/10.4102/hts.v75i2.4850 
Villanueva, S.T., 2013, 'Teaching as a healing craft: Decolonizing the classroom and creating spaces of hopeful resistance through chicano-indigenous pedagogical praxis', Urban Review 45, 23-40. https://doi.org/10.1007/s11256-012-0222-5

Waghid, Y., 2004, 'Compassion, citizenship and education in South Africa: An opportunity for transformation?', International Review of Education 50, 525-542. https://doi.org/10.1007/s11159-004-4638-3.
Waweru, R., 2015, 'Authentic community development: Principles and fundamentals', International Journal of Humanities \& Social Science Studies (IJHSS) 1(V), 64-70, viewed 08 March 2018, from http://oaji.net/ articles/2015/1115-1438670260.pdf

Weyers, M.L., 2011, The theory and practice of community work: A South African perspective, Xerox, PU for CHE, Potchefstroom. 